\title{
Interviews
}

\section{"That's what missionary work is all about, loving people": A Conversation with James Martin, S.J.}

\author{
James Martin, S.J. \\ America Magazine \\ Martin@americamedia.org
}

\begin{abstract}
In his nearly thirty-year preparation for the film Silence, Martin Scorsese called on a number of consultants, including James Martin, S.J., who worked with Mr. Scorsese and the American actors for two years. Here, Father Martin, editor-at-large of America and author of many books including Jesus: A Pilgrimage and the Jesuit Guide to (Almost) Everything (New York, NY : HarperOne, 2014) discusses his participation in what many are calling Scorsese's masterpiece with Robert A. Maryks, associate professor of history at Boston College, where he teaches a course on representations of Jesuits in film.
\end{abstract}

\section{Keywords}

Silence - Martin Scorsese - James Martin, S.J - interview

\section{You were a consultant to Martin Scorsese's film Silence. What exactly} was your role?

Essentially, my role was threefold. First, I helped Martin Scorsese and his co-screenwriter Jay Cocks with the script in various stages of development. Second, I helped the actors in their preparation for their roles as Jesuits, especially Andrew Garfield, whom I directed through the Spiritual Exercises. 
And third, I helped field questions from the production team and helped direct them to the many other Jesuits who helped on this project, especially when they finally began filming in Taiwan. They were greatly helped by Jerry Martinson, S.J., in Taiwan, for example.

Initially, I was contacted by Marianne Bower, who is Martin Scorsese's researcher. She had read my book The Jesuit Guide and had a lot of questions about Jesuit spirituality. The Jesuit history angle was handled by Liam Brockey and David Collins, S.J., mainly, as well as Antoni Üçerler, S.J., whom they had contacted a bit earlier in the process, I believe. Marianne had a great deal of questions about Jesuit formation, prayer, the Exercises, and so on, as well as what you might call questions about more "technical" things, like the way Mass was celebrated.

After that, I started meeting with Marty and Jay, about the script. The first script that I read was superb, but there were several places where things just didn't ring true for a Jesuit. There was little mention of the Spiritual Exercises, for one thing, which would surely have been in the minds and in the hearts of the Jesuits. And on their lips as well. There was also, for example, a kind of surprise on the part of Rodrigues when he first encountering suffering very early in the narrative. And I said to Marty and Jay, "Well, he asked to suffer in the Exercises!" So I suggested changes based on those kinds of things. Now in the film, there are quotes directly from the Exercises, like "What have I done for Christ? What am I doing for Christ? And what will (or ought) I do for Christ?" So it's much more redolent of the Exercises.

Also, the way that the characters prayed and spoke to God, and about God, struck me, for want of a better word, as a bit too formal. So I suggested more "free form" prayer, of the kind that Jesuits would naturally use. Not so many Our Fathers, and more dialogue with God and Jesus directly, "as one friend speaks to another," as Ignatius says in the Exercises. Finally, just making a few corrections about nomenclature and adding more inside-Jesuit words like "first fervor," to underline that these are Jesuits talking to other Jesuits, in the case of Rodrigues, Garupe, and Valignano. I wanted the film to be as Jesuit as possible. And so did Marty and Jay. They were incredibly open to my suggestions and made a great many changes.

Finally, I suggested that in the dialogues and examinations between Rodrigues and Ferreira, and between Rodrigues and Inoue, Rodrigues be given better, sharper answers. Initially Rodrigues seemed entirely outmatched and so I helped sharpen his answers. Because I could know what a Jesuit would probably say in that situation. So I suggested some answers.

Eventually the actors contacted me, one by one. And it was Andrew, who plays the lead, Father Rodrigues, with whom I ended up working most closely. 
Andrew was interested in everything about Jesuit spirituality, and had also expressed interest in making the Spiritual Exercises right off the bat. But since he had very little experience in prayer I balked. Instead I started to give him introductory prayers, like the examen. He took to that very well and, without breaking confidences, I can say that he still asked to make the Exercises. And I still balked as anyone would: it didn't seem to be a good idea, at first, to give the Exercises to someone with such little experience in prayer. So I gave him a few more prayers from the First Week, and then suddenly we were in the Exercises. It was rather astonishing to me, frankly. I had to pray about all this, but it seemed that God simply drew him into the Exercises. Just like that.

Without breaking confidence, I can say that Andrew gave himself totally to them. As generously as any other Jesuit. We met for six months, using the $19^{\text {th }}$ Annotation Retreat, usually in person, though sometimes by Skype when he was in LA or elsewhere. He completed them the day before leaving for Taiwan to start filming.

Before he left I had asked the provincial of the Usa Northeast Province, John Cecero, S.J., if I could "mission" him to do this role. And he agreed. As the Exercises ends, there is a sense of being "sent out," and I also wanted Andrew to feel the Society of Jesus behind him. It was a moving moment for both of us.

Marty said to me, "I'm sorry you won't be in Taiwan, since we won't have an expert in Jesuit spirituality." And I said, "Yes, you will: Andrew."

Adam had also come to me seeking advice, as had Liam, though Liam had worked with Dan Berrigan on The Mission (and his son is at a Jesuit high school-Fordham Prep), so he already knew a bit more. At one point Andrew and Adam were planning on traveling to Portugal to research their roles, and there was a dilemma: Andrew was about to enter the Third Week. So we arranged to have them go to St. Bueno's Retreat House in Wales. There, Andrew did the entire Third Week, day by day, with me (through Skype) and Adam did an eight-day retreat. As it happened then, Andrew did the Third Week more or less as a person does it on a Thirty-Day Retreat.

And at the very end, Marty asked what I thought an appropriate coda should be for the film. So Liam and I came up with "For the Japanese Christians and their pastors." And I added "Ad maiorem Dei gloriam." And that's what you see now, which was very moving for me to see the first time.

Scorsese's Silence is a second adaptation of Shūsaku Endō's novel by the same title. How would you describe the difference between this and Masahiro Shinoda's 1971 Chinmoku.

Ah, no idea! I've not seen it. 


\section{What impact has had Scorsese's Silence on you personally?}

Well, it was rather overwhelming seeing it. I'm not embarrassed to say that I wept when I first saw it. For a long time. It affected me on many levels, and it took me a while to realize why. To unpack it. First, it's a beautiful story. The story itself of the Jesuit missionaries and the Japanese Christians is just a powerful narrative. Second, it's a beautiful film. I think it's Scorsese's masterpiece. Visually it's stunning. The scene of the ocean crucifixion, for example, is breathtaking. Third, I knew the actors, and especially with Andrew, I knew how much they had gone through to realize this. Fourth, it's the story of the Jesuit martyrs, my brothers, and so it was deeply moving to see that portrayed, even if it is fictionalized a bit. Fifth, it is a compelling story of faith. That last scene, which I won't give away, is extraordinary. I wept when I read it in the first script-as I did when I first saw it on film. Finally, I think I was just relieved. It was a long project, and though I had a very small role in it, I took it seriously and was relieved that it came out so beautifully, and so Jesuit.

\section{The late Dan Berrigan was an adviser to Roland Joffé's Mission. Do you think he did a good job? What different suggestions you would have given to Joffé?}

Well, I do of course. I'm not sure what his role was precisely-though Liam told me that they celebrated Mass every day on the set-but I think the film is a good one. Dan even wrote a whole book on his experiences on the set, The Mission: A Film Journal. If I had one critique of The Mission, it would be something I recommended to Scorsese and Cocks, which is, let the viewer see the joy of Jesuit ministry. The Mission is a bit dour: both Jeremy Irons and Robert De Niro are a bit grim. For Silence I kept encouraging Marty and Jay to add more scenes of ministry and being with the people and even laughing with one another. There is one scene where Rodrigues says to Garupe playfully, "You're a bad priest." And I said, "Oh no, a Jesuit would say, 'You're a bad Jesuit!'” Without joy, the viewer wonders, "Who would ever choose this life?”

There are a number of other films that represent Jesuits in a variety of ways: There is Irvin Kershner's The Hoodlum Priest, William Friedkin's The Exorcist, Bruce Beresford's Black Robe, and Costa-Gavras's Amen, among others. Is the portrayal of the Jesuits there accurate?

Well, I've only seen a few of them. In The Exorcist you have a younger, sort of hippy priest, played by Jason Miller, and the older priest, played by Max von Sydow. Of course The Exorcist, based on a real-life case, is more of a horror 
film and less a film about faith, in my eyes, and so the portrayals of the Jesuits, while accurate, are a bit arch. Mainly as foils for Satan, who I would suggest is the real lead in that film. But I did appreciate Max von Sydow's doggedness. I'm a big fan of Black Robe, about the North American martyrs, though some of my Jesuit brothers are not. I think that film comes down in the end to the final question, posed by the Native Americans to the Jesuit Father LaForgue, "Do you love us?" In response, there is a montage of all the faces that he's known in his ministry, as he recalls them, and the obvious answer is yes.

That's what missionary work is all about, loving people. Frankly, that's what the Jesuit mission overall is about. It's clear in Silence that Rodrigues and Garupe and even Ferreira love the people they were sent to minister to. The deep question that the film poses though is: How? 
